\title{
Pengaruh Pelaksanaan Program Keselamatan dan Kesehatan Kerja Terhadap Produktivitas Kerja Karyawan
}

\author{
Renita Hadiyanti $^{1 *}$ dan Maya Setiawardani ${ }^{2}$ \\ ${ }^{1}$ Jurusan Administrasi Niaga, Politeknik Negeri Bandung, Indonesia \\ 2 Jurusan Administrasi Niaga, Politeknik Negeri Bandung, Indonesia
}

\begin{abstract}
:
Human resources is a living asset owned by an organization that has an important role for the success of an organization. The success of human resource management as one of the benchmarks is in terms of employee productivity. The needs of employees in carrying out their work in order to achieve optimal work productivity need to be protected with a safe working environment, comfortable and serene, because it will cause the desire to work well. This research was conducted with the aim to know how the implementation of occupational safety and health program, how the productivity of employees work, and how much influence the implementation of occupational safety and health program on employees work productivity at PT Papyrus Sakti Paper Mill. The data collection tool in this research is by distributing questionnaires to 125 employees of production department. Analytical techniques used in the form of descriptive analysis techniques with quantitative approach. The result of descriptive statistical analysis for both variables shows the safety and health variables with employee productivity are in good category. Based on the results of testing on the implementation of occupational safety and health have a positive and significant effect on work productivity of employees. It can be proven from the calculation $t$ count $=6.359>t$ table $=1.979$ with the percentage of influence of $24.7 \%$.
\end{abstract}

Keywords: occupational safety, occupational health, occupational health and safety program, work productivity

\begin{abstract}
Abstrak:
Sumber daya manusia merupakan aset hidup yang dimiliki oleh organisasi yang memiliki peranan penting bagi keberhasilan suatu organisasi. Keberhasilan manajemen sumber daya manusia yang dijadikan salah satu tolak ukur adalah dalam hal produktifitas karyawan. Kebutuhan karyawan dalam melaksanakan pekerjaannya agar dapat mencapai produktifitas kerja yang optimal perlu mendapat perlindungan dengan adanya lingkungan kerja yang aman, nyaman dan tenteram, karena akan menimbulkan keinginan untuk bekerja dengan baik. Penelitian ini dilakukan dengan tujuan untuk mengetahui bagaimana pelaksanaan program keselamatan dan kesehatan kerja, bagaimana produktivitas kerja karyawan, dan seberapa besar pengaruh pelaksanaan program keselamatan dan kesehatan kerja terhadap produktivitas kerja karyawan di PT Papyrus Sakti Paper Mill. Alat pengumpulan data dalam penelitian ini adalah dengan menyebarkan kuesioner kepada 125 orang karyawan bagian produksi. Teknik analisis yang digunakan berupa teknik analisis deskriptif dengan pendekatan kuantitatif. Hasil analisis statistik deskriptif untuk kedua variabel menunjukkan variabel keselamatan dan kesehatan kerja dengan produktivitas kerja karyawan berada pada kategori baik. Berdasarkan
\end{abstract}

\footnotetext{
*Email korespondensi:

Renita Hadiyanti

hadiyanti.renita18@gmail.com
}

Jurnal Riset Bisnis \& Investasi 
hasil pengujian mengenai pelaksananaan keselamatan dan kesehatan kerja berpengaruh positif dan signifikan terhadap produktivitas kerja karyawan. Hal itu dapat dibuktikan dari hasil perhitungan $\mathrm{t}$ hitung $=6,359>\mathrm{t}$ tabel $=1,979$ dengan pengaruh sebesar $24,7 \%$.

Kata Kunci: keselamatan kerja, kesehatan kerja, program keselamatan dan kesehatan kerja, produktivitas kerja

\section{PENDAHULUAN}

Sumber daya manusia merupakan asset hidup yang dimiliki oleh organisasi yang memiliki peranan penting bagi keberhasilan suatu organisasi, karena mereka yang akan menjalankan tujuan dan sasaran organisasi tersebut. Sumber daya manusia harus mendapatkan perhatian serius dan dikelola dengan sebaik mungkin. Hal ini dimaksudkan agat sumber daya manusia yang dimiliki perusahaan mampu memberikan kontribusi yang optimal dalam upaya pencapaian tujuan organisasi. Dalam pengelolaan sumber daya inilah diperlukan manajemen yang mampu mengelola sumber daya secara sistematis, terencana, dan efisien. Karena itu sumber daya manusia harus dikelola dengan profesional, dimana aspek bisnis tetap menjadi perhatian yang serius untuk menjaga kelangsungan usaha. Akan tetapi, tidak meninggalkan unsur sosial sehingga perusahaan mampu mencapai tingkat pertumbuhan dan perkembangan organisasi, mempertahankan profitabilitas organisasi, menciptakan efisiensi keunggulan kualitas pelayanan, serta inovatif dalam merespon kebutuhan perusahaan.

Setiap perusahaan selalu ingin dan berusaha supaya setiap karyawannya memiliki produktivitas kerja yang tinggi. Oleh karena itu, perusahaan harus mampu mempertahankan dan meningkatkan produktivitas karyawannya agar tujuan perusahaan dapat tercapai seoptimal mungkin. Berdasarkan hasil studi dokumentasi yang telah dilakukan di PT Papyrus Sakti Paper Mill telah mengalami penurunan produktivitas kerja atau tidak mencapai produktivitas yang telah ditetapkan oleh perusahaan.
Masalah rendahnya produktivitas kerja merupakan masalah yang harus diperhatikan oleh perusahaan karena produktivitas kerja karyawan dapat mempengaruhi kualitas dan kuantitas perusahaan dalam menghadapi persaingan dan menjadi kunci utama dalam mencapai tujuan perusahaan.

Kebutuhan karyawan dalam melaksanakan pekerjaannya agar dapat mencapai produktivitas kerja yang optimal perlu mendapat perlindungan dengan adanya lingkungan kerja yang aman, nyaman dan tentram, karena akan menimbulkan keinginan karyawan untuk bekerja dengan baik. Semakin tersedianya fasilitas keselamatan kerja semakin sedikit kemungkinan terjadinya kecelakaan kerja. Selain keselamatan kerja, kesehatan kerja juga merupakan faktor yang penting. Faktor keamanan dan perlindungan dalam bekerja menjadi salah satu faktor yang mempengaruhi produktivitas kerja karyawan. Salah satu upaya dalam menerapkan perlindungan bagi karyawan adalah dengan melaksanakan program keselamatan dan kesehatan kerja. Program keselamatan dan kesehatan kerja merupakan suatu sistem program yang dibuat bagi pekerja maupun pengusaha sebagai upaya pencegahan timbulnya kecelakaan kerja dan penyakit akibat hubungan kerja dalam lingkungan kerja dengan cara mengenali hal-hal yang berpotensi menimbulkan kecelakaan kerja serta tindakan antisipasi bila terjadi hal demikian.

Kesehatan kerja yang menunjuk pada bebas dari gangguan fisik maupun mental yang dapat berasal dari lingkungan kerja. Kondisi aman dan sehat memberikan umpan balik yang positif yang akan mendorong produktifitas kerja yang baik dan prestasi 
kerja. Keselamatan dan kesehatan kerja memang merupakan salah satu persyaratan untuk meningkatkan produktivitas kerja karyawan yang erat kaitannya dengan hasil produksi. Pada dasarnya keselamatan dan kesehatan kerja adalah upaya mencegah/ menghindari/ mengurangi kecelakaan kerja dengan cara menghentikan/ meniadakan/ menghilangkan resiko atau unsur bahaya guna mencapai target kerja/ target produksi.

Dengan meningkatkan keselamatan dan kesehatan tempat kerja, perusahaan dapat mengurangi pengeluaran sekaligus memenuhi kebutuhan pegawainya, serta memenuhi kewajiban mereka bagi masyarakat luas. Karena program K3 dapat menghasilkan sumber daya manusia yang lebih produktif yang dapat melaksanakan pekerjaan secara kreatif.

Pada umumnya kcelakaan kerja disebabkan oleh dua faktor, yaitu faktor manusia dan lingkungan. Kecelakaan kerja yang disebabkan oleh faktor manusia yaitu dari tindakan yang tidak aman dari manusia, seperti tidak mentaati peraturan keselamatan kerja yang telah ditetapkan perusahaan. Sedangkan dilihat dari faktor lingkungan kerja biasanya menyangkut antara lain mesin-mesin atau peralatan dan perlengkapan.

Terjadinya kecelakaan kerja tentu saja menjadi masalah yang besar bagi kelangsungan suatu usaha, kerugian yang diderita tidak hanya berupa kerugian materi yang cukup besar namun lebih dari itu adalah timbulnya korban jiwa yang tidak sedikit jumlahnya. Kehilangan sumber daya manusia adalah satu-satunya sumber daya yang tidak dapat digantikan oleh teknologi apapun. Dengan menerapkan program keselamatan dan kesehatan kerja maka dapat menekan jumlah kecelakaan kerja dan perusahaan tidak akan mengalami suatu kerugian.

Setiap pekerjaan selalu mengandung potensi resiko bahaya dalam bentuk kecelakaan dan penyakit kerja. Besarnya potensi kecelakaan tersebut tergantung dari jenis tata ruang dan lingkungan bangunan serta kualitas manajemen dan tenaga-tenaga pelaksana.

PT Papyrus Sakti Paper Mill merupakan perusahaan yang bergerak dalam bidang produksi kertas board yang biasa disebut dengan coated duplex board (CDB) ini, merupakan salah satu perusahaan yang peduli dengan keselamatan dan kesehatan kerja, hal ini dapat dilihat dari salah satu kebijakan mutu dari perusahaan tersebut yaitu mengenai program keselamatan dan kesehatan kerja serta pengelolaan lingkungan. Kebijakan tersebut meliputi menjaga keselamatan dan kesehatan karyawan yang dapat ditimbulkan baik dalam proses produksi ataupun proses pendukungnya, serta menjaga lingkungan kerja untuk mengurangi efek yang dapat merugikan baik itu hasil produk, proses produksi, maupun karyawan itu sendiri. Dengan sasaran mutu mengenai kebijakan keselamatan dan kesehatan kerja mencakup usaha mengurangi kecelakaan kerja, pencapaian standar baku mutu lingkungan, serta meningkatkan kesadaran karyawan untuk menggunakan atau memakai alat-alat $\mathrm{K} 3$ yang disediakan.

Kecelakaan kerja di PT Papyrus Sakti Paper Mill berdasarkan hasil wawancara dan data kecelakaan kerja yang ada di perusahaan menunujukkan bahwa setiap tahun selalu terjadi kecelakaan kerja. Hal tersebut menunjukkan bahwa target perusahaan dalam kecelakaan kerja yaitu zero accident masih belum tercapai. Sedangkan untuk kesehatan karyawan dilihat dari data absensi sakit masih cukup tinggi.

\section{KAJIAN LITERATUR}

\section{Keselamatan dan Kesehatan Kerja (K3)}

Dalam proses pemanfaatan sumber daya manusia terdapat sebuah aktivitasaktivitas yang mencoba untuk memfasilitasi orang-orang yang ada didalam organisasi untuk dapat berkontribusi dalam pencapaian rencana strategis organisasi. Salah satu aktivitas sumber daya manusia adalah program keselamatan dan kesehatan kerja 
yang dapat melindungi pekerja dari bahaya di tempat kerja serta dapat meningkatkan produktivitas kerjanya (Jackson, Schuler \& Werner, 2011).

Keselamatan dan kesehatan kerja berkaitan dengan upaya pencegahan kecelakaan dan penyakit akibat kerja serta memiliki jangkauan berupa terciptanya masyarakat dan lingkungan kerja yang aman, sehat dan sejahtera. Banyaknya kasus kecelakaan kerja yang terjadi di tempat kerja yang dapat menimbulkan dampak negatif, tidak saja bagi perusahaan bahkan merugikan manusia. Undang-undang Nomor 14 tahun 1969 pasal 9 mengutarakan bahwa: tiap tenaga kerja berhak mendapatkan perlindungan atau keselamatan, kesehatan, kesusilaan, pemeliharaan moral kerja serta perlakuan yang sesuai dengan martabat manusia dan moral agama.

K3 mengacu pada kondisi fisiologisfisikal dan psikologis pekerja yang merupakan hasil dari lingkungan yang diberikan oleh perusahaan. Jika suatu perusahaan melakukan pengukuran keamanan dan kesehatan yang efektif, maka semakin sedikit pegawai yang akan mengalami dampak penyakit jangka pendek atau jangka panjang akibat bekerja di perusahaan tersebut (Jackson, Schuler \& Werner, 2011).

Sedarmayanti

(2010:208)

menyatakan dalam menerapkan sistem manajemen K3 organisasi wajib melaksanakan ketentuan sebagai berikut:

1. Menetapkan kebijakan K3 dan menjamin komitmen terhadap penerapan sistem manajemen K3.

2. Merencanakan pemenuhan kebijakan tujuan dan sasaran penerapan keselamatan dan kesehatan kerja.

3. Menerapkan kebijakan keselamatan dan kesehatan kerja secara efektif dengan mengembangkan kemampuan dan mekanisme pendukung yang diperlukan mencapai kebijakan, tujuan, sasaran, keselamatan dan kesehatan kerja.

4. Mengukur, memantau, dan mengevaluasi kinerja keselamatan dan kesehatan kerja serta melakukan tindakan perbaikan dan pencegahan.

5. Meninjau secara teratur dan meningkatkan pelaksanaan sistem manajemen K3 secara berkesinambungan dengan tujuan meningkatkan kinerja keselamatan dan kesehatan kerja.

Berdasasarkan penjelasan di atas dapat disimpulkan bahwa keselamatan dan kesehatan kerja merupakan hal yang penting bagi suatu perusahaan karena dampak terjadinya suatu kecelakaan kerja tidak hanya merugikan karyawan tetapi juga perusahaan secara langsung. Oleh karena itu, penanganan masalah keselamatan dan kesehatan kerja di dalam sebuah perusahaan harus diperhatikan dan ditangani secara serius oleh seluruh komponen pelaku usaha dan pelaksanaan keselamatan dan kesehatan kerja yang terorganisir dengan baik yang tentunya akan mengurangi terjadinya kecelakaan kerja. Yang dimaksud dengan terorganisir dengan baik disini adalah terpenuhinya semua aspek syarat-syarat keselamatan kerja sesuai dengan pasal 3 UU Nomor 1 Tahun 1970, terpenuhinya lingkungan kerja yang sehat dengan terbebas dari penyakit akibat kerja baik dari golongan fisik, golongan kimia, golongan biologis, golongan fisiologis, dan golongan psikologi.

\section{Tujuan Program Keselamatan dan Kesehatan Kerja}

Tujuan inti dari pelaksanaan program keselamatan dan kesehatan kerja adalah memberi perlindungan kepada karyawan. Dengan adanya jaminan keselamatan, keamanan, dan kesehatan selama bekerja, karyawan akan memberikan kepuasan dan meningkatkan loyalitas terhadap perusahaan. Sedarmayanti (2010) mengemukakan bahwa tujuan dari sistem manajemen keselamatan dan kesehatan kerja adalah:

1. Sebagai alat mencapai derajat kesehatan tenaga kerja yang setinggi-tingginya, baik buruh, petani, nelayan, pegawai negeri, atau pekerja bebas. 
2. Sebagai upaya mencegah dan memberantas penyakit dan kecelakaan akibat kerja, memelihara, dan meningkatkan kesehatan dan gizi tenaga kerja, merawat dan meningkatkan efisiensi dan daya produktivitas tenaga manusia, memberantas kelelahan kerja dan melipatgandakan gairah serta kenikmatan bekerja.

3. Memberi perlindungan bagi masyarakat sekitar perusahaan, agar terhindar dari bahaya pengotoran bahan proses industrialisasi yang bersangkutan, dan perlindungan masyarakat luas dari bahaya yang mungkin ditimbulkan oleh produk industri.

Sedangkan menurut Mangkunegara (2011;162), tujuan keselamatan dan kesehatan kerja, yaitu:

1. Agar setiap karyawan mendapat jaminan keselamatan dan kesehatan kerja, baik secara fisik, sosial dan psikologis.

2. Agar setiap perlengkapan dan peralatan kerja yang digunakan sebaik-baiknya, seefektif mungkin.

3. Agar semua hasil produksi dipelihara keamanannya.

4. Agar adanya jaminan atas pemeliharaan dan peningkatan kesehatan gizi karyawan.

5. Agar meningkatkan kegairahan, keserasian kerja dan partisipasi kerja.

6. Agar terhindar dari gangguan kesehatan yang disebabkan oleh lingkungan atau kondisi kerja.

7. Agar setiap pegawai merasa aman dan terlindungi dalam bekerja.

Jadi dapat disimpulkan bahwa tujuan dari keselamatan dan kesehatan kerja adalah untuk dapat membuat lingkungan kerja yang aman, nyaman, terhindar dari kecelakaan kerja yang dapat terjadi, dan melindungi tenaga kerja dari gangguan kesehatan yang disebabkan oleh kondisi lingkungan kerja.

\section{Indikator Keselamatan dan Kesehatan Kerja}

Handoko (2000) mengemukakan bahwa strategi atau upaya untuk mengukur dan meningkatkan keselamatan dan kesehatan kerja yang efektif dapat dilihat dari 5 (lima) dimensi, yaitu:

1. Membuat kondisi kerja yang aman. Dalam rangka upaya meningkatkan keselamatan dan kesehatan kerja, maka suatu pencegahan kecelakaan serta penyakit akibat kerja harus dimulai dari membuat kondisi kerja yang aman. Kondisi kerja merupakan serangkaian kondisi atau keadaan lingkungan kerja dari perusahaan yang menjadi tempat karyawan bekerja didalam lingkungan tersebut. Membuat kondisi kerja yang aman dapat dilakukan dengan merancang lingkungan kerja dengan baik yang merupakan salah satu upaya terbaik untuk mencegah dan meningkatkan keselamatan dan kesehatan kerja.

2. Pendidikan dan pelatihan. Pelatihan keselamatan dan kesehatan kerja merupakan pelatihan yang disusun untuk memberi bekal kepada personil yang ditunjuk perusahaan untuk dapat menerapkan K3 di tempat kerja. Pelatihan ini bertujuan agar karyawan dapat memahami program keselamatan dan kesehatan kerja dan berperilaku sesuai dengan aturan atau pedoman yang telah ditetapkan perusahaan.

3. Menciptakan lingkungan kerja yang sehat. Lingkungan kerja merupakan segala yang ada disekitar para pekerja ketika melakukan pekerjaan yang dapt mempengaruhi pekerja itu sendiri dalam menjalankan tugas yang dibebankan. Penyakit kerja dapat lebih merugikan dan berbahaya daripada kecelakaan kerja. Karena penyakit sering kali membutuhkan waktu lama untuk berkembang, kondisi kerja yang berbahaya bisa tidak terdeteksi selama beberapa tahun. Mengembangkan strategi untuk mengurangi tingkat kejadian penyakit ini biasanya lebih sulit daripada mengurangi kecelakaan dan cedera.

4. Pelayanan kebutuhan kesehatan karyawan. Program manajemen dalam 
memberikan program yang dirancang untuk membantu pegawai dalam menghadapi tekanan terkait dengan pekerjaan merupakan strategi untuk meningkatkan keselamatan dan kesehatan kerja. Program ini diharapkan dapat mengurangi tekanan yang dialami oleh pegawai.

5. Pelayanan kesehatan. Jaminan keselamatan dan kesehatan kerja para tenaga kerja harus diutamakan dan diperhitungkan, agar para tenaga kerja merasa nyaman dan aman dengan adanya jaminan atas pekerjaan yang mereka lakukan.

\section{Produktivitas Kerja}

Menurut Sunyoto (2015), secara teknis produktivitas merupakan perbandingan antara hasil yang dicapai dan keseluruhan sumber daya yang dipergunakan, produktivitas tenaga kerja merupakan persatuan waktu dan sebagai tolak ukur jika ekspansi dan aktivitas dari sikap sumber yang digunakan selama produktivitas berlangsung dengan membandingkan jumlah yang dihasilkan dengan setiap sumber yang digunakan. Jadi produktivitas kerja adalah ukuran yang menunjukkan pertimbangan antara input dan output yang dikeluarkan perusahaan serta peran tenaga kerja yang dimiliki persatuan waktu. Atau dengan kata lain mengukur efisiensi memerlukan identifikasi dari hasil kinerja.

Produktivitas ini merupakan suatu aspek yang penting bagi perusahaan, karena apabila tenaga kerja dalam perusahaan mempunyai kerja yang tinggi, maka perusahaan akan memperoleh keuntungan dan hidup perusahaan akan terjamin. Usaha peningkatan produktivitas harus direncanakan secara baik dan sistematis, sehingga berhasil apabila diaplikasikan kedalam suatu perusahaan (Hameed \& Amjad, 2009). Sedangkan menurut Tryono (2012;61), produktivitas adalah perbandingan antara hasil-hasil yang dicapai dengan keseluruhan sumber daya yang dipergunakan atau perbandingan jumlah produksi (output) dengan sumber daya yang digunakan (input).

Sedangkan menurut Sinungan (2009) produktivitas kerja adalah sikap yang timbul untuk menggunakan sumberdaya dalam organisasi secara tepat guna, efektif dan efesien. Dimana seseorang bekerja lebih baik dari hari ke hari, dan pekerjaan yang dilakukan harus lebih meningkat kualitasnya. Hal ini sejalan dengan yang dikemukakan oleh Widodo (2008:260) bahwa produktivitas adalah perbandingan antara hasil yang dicapai dengan peran serta tenaga kerja disini adalah penggunaan sumber daya manusia secara efektif dan efisien.

Mengingat pentingnya peranan manusia dalam suatu perusahaan, yang apabila salah memanfaatkan tenaga kerja manusia tersebut akan dapat menimbulkan masalah yang sangat rumit, yang justru bisa menghancurkan tujuan perusahaan yang berangkutan. Untuk itu, tenaga kerja manusia sangat perlu mendapatkan perhatian yang khusus karena pemakaian tenaga kerja manusia secara efektif merupakan kunci dari peningkatan produktivitas (Ardana, Mujiati \& Utama, 2012).

Berdasarkan pengertian diatas maka dapat disimpulkan bahwa produktivitas kerja adalah penggunaan sumber daya manusia, keterampilan, teknologi dan manajemen untuk memperbaiki kehidupan agar menjadi lebih baik dari hari sebelumnya. Produktivitas kerja juga mengandung pengertian sebagai perbandingan antara hasil yang dicapai dengan peran serta tenaga kerja per satuan waktu dan merupakan hasil keluaran tiap karyawan yang efektif dari pemamfaatan sumber daya yang efesien. Seorang karyawan dapat dikatakan produktif apabila ia mampu menghasilkan jumlah produk yang lebih banyak dibandingkan dengan karyawan lain dalam waktu yang sama. 


\section{Indikator Produktivitas Kerja}

Sedarmayanti (2004:35) berpendapat bahwa terdapat 2 (dua) dimensi yang dapat dijadikan pengukuran produktivitas yaitu:

1. Efektivitas. Efektivitas merupakan suatu ukuran yang memberikan gambaran seberapa jauh target dapat tercapai. Efektivitas mengarah kepada pencapaian kerja yang maksimal yaitu pencapaian target yang berkaitan dengan dua indikator, yaitu pencapaian kualitas dan kuantitas produk yang dihasilkan

2. Efisiensi. Efisiensi mengarah kepada seberapa hemat masukan sumber daya yang digunakan baik secara teknis maupun ekonomis untuk menghasilkan keluaran seperti yang telah ditentukan.

\section{Hubungan Pelaksanaan Program Keselamatan dan Kesehatan Kerja Terhadap Produktivitas Kerja}

Untuk mencapai produktivitas kerja yang tinggi suatu perusahaan harus mampu mendapatkan, mengembangakan, mengevaluasi, dan memelihara kualitas dan kuantitas tenaga kerja yang tepat. Salah satu cara memelihara kualitas dan kuantitas tenaga kerja adalah menjamin K3 dilingkungan perusahaan. Karyawan yang terjamin keselamatan dan kesehatan kerjanya akan bekerja lebih produktif dibandingkan mereka yang tidak terjamin keselamatan dan kesehatannya.

Menurut Rachmawati (2008), karyawan yang memiliki kesejahteraan buruk akan mempengaruhi produktivitasnya. Lebih lanjut mereka tidak mempunyai motivasi dan minat, apatis dalam bekerja, serta loyalitas terhadap perkejaan akan berkurang. Berikut beberapa faktor yang dapat meningkatkan produktivitas kerja:

1. Pengaturan jam kerja

Kaitan antara jam kerja dengan produktivitas kerja adalah bahwa kondisi karyawan dapat dipengaruhi oleh kurangnya istirahat yang memadai sehingga mengakibatkan kondisi psikis dan mental menurun.
2. Kemudahan menghemat waktu dan efisiensi kerja

a. Sistem shift yang didukung oleh model upah shift

b. Kenyamanan kerja

c. Keamanan kerja

d. Keselamatan dan kesehatan kerja gaya baru (K3GB)

Setiap perusahaan yang baik dan sehat adalah perusahaan yang selalu memperhatikan kondisi karyawannya. Penerapan program keselamatan dan kesehatan kerja yang optimal bagi karyawan berhubungan erat dengan produktivitas kerja karyawannya, karena penerapan program keselamatan dan kesehatan kerja merupakan salah satu cara memotivasi karyawan untuk meningkatkan produktivitas kerja mereka.

Penyakit akibat kerja bila tidak ditangani secara sungguh-sunguh dan terpadu, dapat menjadi bumerang bagi pekerja dan perusahaan di tempat mana mereka bekerja. Bagi tenaga kerja, penyakit akibat kerja dapat menurunkan pendapatan yang diterimanya. Sedangkan bagi perusahaan berakibat menurunnya jumlah produksi serta memberikan citra yang kurang baik terhadap kualitas dan kapasitas perusahaan. Pekerja yang kesejahteraannya buruk, tidak hanya menyebabkan rasa kecil hati tetapi produktivitas mereka akan menurun. Lebih lanjut mereka tidak menaruh minat, apabila dalam melakukan pekerjaan dan loyalitas mereka terhadap perusahaan akan berkurang pula.

Pusparini, Jusuf, dan Budiono (2008) menyatakan bahwa program keselamatan kerja salah satu tujuannya adalah melindungi tenaga kerja atas hak keselamatannya dalam melakukan pekerjaan untuk kesejahteraan hidup dan meningkatkan produksi dan produktivitas. Hal itu ditegaskan pula oleh Sedamaryanti (2009) bahwa program keselamatan kerja akan meningkatkan produktivitas kerja dari tenaga kerja.

Pencegahan kecelakaan kerja adalah suatu bagian utama dari fungsi pemeliharaan karyawan. Kondisi fisik karyawan dapat 
ditinjau melalui penyakit, ketegangan, dan tekanan seperti halnya melalui kecelakaan sebagian besar usaha K3 sedang diarahkan pada pencegahan penyakit yang timbul dari lingkungan tempat kerja lebih-lebih lagi, kesehatan karyawan yang telah mengakibatkan suatu tingkat ketidakhadiran yang tinggi dan produktivitas kerja yang rendah.

Berdasarkan uraian di atas, pelaksanaan program keselamatan dan kesehatan kerja serta produktivitas karyawan menjadi penting dikaji, karena kedua faktor tersebut dapat mempengaruhi produktivitas perusahaan dalam tujuannya mencapai visi dan misi perusahaan. Mengingat hal itu, setiap perusahaan perlu menerapkan program keselamatan dan kesehatan kerja yang secara komprehensif mengupayakan pencegahan kecelakaan dan penyakit kerja. Sehingga dapat meningkatkan produktivitas kerja karyawannya.

Oleh karena itu hipotesis dalam penelitian ini adalah:

$\mathrm{H}_{\mathrm{o}} \quad$ : Tidak ada pengaruh yang positif dan signifikan antara pelaksanaan program keselamatan dan kesehatan kerja terhadap produktivitas kerja.

$\mathrm{H}_{\mathrm{a}}$ : Ada pengaruh yang positif dan signifikan antara pelaksanaan program keselamatan dan kesehatan kerja terhadap produktivitas kerja.

\section{METODE PENELITIAN}

Penelitian ini dilakukan untuk mengetahui pengaruh keselamatan dan kesehatan kerja terhadap produktivitas kerja karyawan. Jenis penelitian yang digunakan adalah penelitan analisis deskriptif dengan pendekatan kuantitatif. Data yang dikumpulkan dalam penelitian ini ada dua jenis, yaitu data primer dan data sekunder.

Data primer merupakan data yang diperoleh dari perusahaan yang bersangkutan, dalam penelitian ini data yang digunakan sebagai data primer adalah hasil dari jawaban responden dari penyebaran kuesioner yang dilakukan. Sedangkan data sekunder adalah data yang diperoleh melalui pengumpulan dokumen-dokumen yang telah ada pada PT Papyrus Sakti Paper Mill, dari jurnal-jurnal ilmiah, buku, dan hasil penelitian sebelumnya yang berkaitan dengan keselamatan dan kesehatan kerja dan produktivitas kerja.

\section{Populasi dan Sampel}

Populasi dalam penelitian ini merupakan karyawan bagian produksi di PT Papyrus Sakti Paper Mill. Penelitian ini menggunakan teknik sampling, dimana teknik sampling ini hanya mengambil sabagian dari populasi. Teknik sampling yang digunakan dalam penelitian ini adalah non probability sampling. Sampel yang digunakan dalam penelitian berjumlah 125 orang karyawan dari jumlah populasi yaitu 181 orang. Jumlah tersebut didapatkan dari hasil perhitungan sampel menggunakan rumus Slovin.

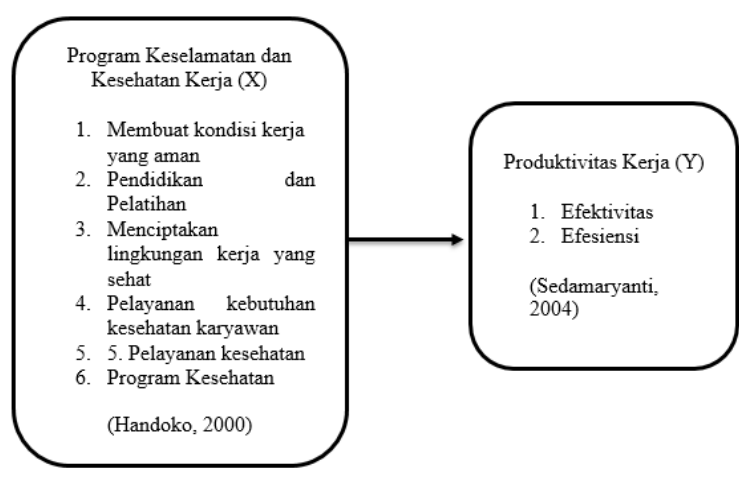

Gambar 1 Model Penelitian

\section{HASIL DAN PEMBAHASAN}

Responden dalam penelitian ini adalah 125 orang karyawan dari bidang produksi, yang diantaranya 72 orang berjenis kelamin laki-laki dan sisanya wanita sebanyak 53 orang. Rentan usianya rata-rata lebih dari 40 tahun yaitu sebanyak 92 orang. Sedangkan sisanya berada berada pada usia rentang 20 sama 40 tahun dengan lama bekerja kebanyakan lebih dari 15 tahun.

\section{Analisis Deskriptif}

Analisis deskriptif digunakan untuk mengetahui distribusi frekuensi jawaban 
responden berdasarkan hasil kuesioner yang telah diisi oleh 125 responden yaitu karyawan bagian produksi PT Papyrus Sakti Paper Mill. Analisis deskriptif ini bertujuan untuk mendeskripsikan variabel keselamatan dan kesehatan kerja dan produktivitas kerja.

Analisis deskriptif ini digunakan untuk menjawab rumusan masalah yang pertama dalam penelitian ini, yaitu bagaimana pelaksanaan program keselamatan dan kesehatan kerja. Berikut ini hasil analisis deskriptif variabel keselamatan dan kesehatan kerja.

Tabel 1 Hasil Analisis Deskriptif Variabel Keselamatan dan Kesehatan Kerja

\begin{tabular}{|l|c|c|c|c|c|}
\hline & $\mathrm{N}$ & Min & Max & Mean & SD \\
\hline $\begin{array}{l}\text { Kondisi kerja } \\
\text { yang aman }\end{array}$ & 125 & 3 & 5 & 4,07 & 0,373 \\
\hline $\begin{array}{l}\text { Pendidikan } \\
\text { dan pelatihan }\end{array}$ & 125 & 2 & 5 & 3,96 & 0,496 \\
\hline $\begin{array}{l}\text { Lingkungan } \\
\text { kerja yang } \\
\text { sehat }\end{array}$ & 125 & 2 & 5 & 3,89 & 0,570 \\
\hline $\begin{array}{l}\text { Pelayanan } \\
\text { kebutuhan } \\
\text { kesehatan } \\
\text { karyawan }\end{array}$ & 125 & 2 & 5 & 4,19 & 0,515 \\
\hline $\begin{array}{l}\text { Pelayanan } \\
\text { kesehatan }\end{array}$ & 125 & 3 & 5 & 4,07 & 0,494 \\
\hline $\begin{array}{l}\text { Keselamatan } \\
\text { dan Kesehatan } \\
\text { Kerja }\end{array}$ & 125 & 3 & 5 & 4,05 & 0,384 \\
\hline
\end{tabular}

Sumber: Hasil Olah Data SPSS (2017)

Pada Tabel 1 dapat diketahui bahwa variabel keselamatan dan kesehatan kerja memiliki nilai mean sebesar 4,05 dengan standar deviasi 0,384. Hasil dari rata-rata variabel keselamatan dan kesehatan kerja tersebut termasuk pada kategori tinggi yang berarti pelaksanaan keselamatan dan kesehatan kerja yang ada pada PT Papyrus Sakti Paper Mill sudah baik. Standar deviasi variabel keselamatan dan kesehatan kerja menunjukkan angka 0,384 atau sama dengan 9,48\% dari nilai mean. Jika nilai standar deviasi di bawah $20 \%$, hal ini menandakan bahwa sebagian besar responden didalam menjawab pernyataan dalam variabel penelitian ini dengan jawaban yang relatif sama.

Tabel 2. Hasil Analisis Deskriptif Produktivitas Kerja

\begin{tabular}{|l|c|r|r|r|r|}
\hline & $\mathrm{N}$ & Min & Max & Mean & \multicolumn{1}{c|}{ SD } \\
\hline Efektivitas & 125 & 3 & 5 & 4,10 &, 349 \\
\hline Efisiensi & 125 & 3 & 5 & 3,84 &, 430 \\
\hline $\begin{array}{l}\text { Produktivitas } \\
\text { Kerja }\end{array}$ & 125 & 3 & 5 & 4,01 &, 350 \\
\hline
\end{tabular}

Sumber: Hasil Olah Data SPSS (2017)

Sedangkan dari Tabel 2 dapat diketahui bahwa rata-rata variabel produktivitas kerja karyawan sebesar 4,01. Hal ini menyatakan bahwa produktivitas kerja karyawan di PT Papyrus Sakti Paper Mill sudah terlaksana dengan baik.

\section{Uji Korelasi Keselamatan dan Kesehatan Kerja dan Produktivitas Kerja Karyawan}

Metode analisis korelasi sederhana ini digunakan untuk mengetahui adanya hubungan antar variabel, dimana variabel bebas dalam penelitian ini adalah keselamatan dan kesehatan kerja (X) sedangkan variabel terikatnya adalah produktivitas kerja karyawan $(\mathrm{Y})$.

Tabel 3. Hasil Uji Korelasi

\begin{tabular}{|l|l|r|r|}
\hline \multicolumn{2}{|l|}{} & \multicolumn{1}{|c|}{ X } & \multicolumn{1}{|c|}{ Y } \\
\hline \multirow{3}{*}{$\mathrm{X}$} & Pearson Correlation & 1 & $.497^{* *}$ \\
\cline { 2 - 4 } & Sig. (2-tailed) & & .000 \\
\cline { 2 - 4 } & $\mathrm{N}$ & 125 & 125 \\
\hline \multirow{3}{*}{$\mathrm{Y}$} & Pearson Correlation & $.497^{* *}$ & 1 \\
\cline { 2 - 4 } & Sig. (2-tailed) & .000 & \\
\cline { 2 - 4 } & $\mathrm{N}$ & 125 & 125 \\
\hline \multirow{2}{*}{$\begin{array}{l}* * . \\
\text { tailed). } \\
\text { tarelation is significant at the 0.01 level (2- }\end{array}$}
\end{tabular}

Sumber: Hasil Olah Data SPSS (2017)

Pada Tabel 3 dapat dilihat korelasi antara variabel keselamatan dan kesehatan kerja dengan produktivitas kerja karyawan 0,497, yang berarti terdapat hubungan positif yang sedang antara keselamatan dan kesehatan kerja dengan produktivitas kerja karyawan pada PT Papyrus Sakti Paper Mill.

\section{Uji Regresi Linear Sederhana}

Analisis regresi digunakan untuk mengetahui seberapa besar pengaruh keselamatan dan kesehatan kerja terhadap 
produktivitas kerja karyawan. Berikut ini diperoleh hasil analisis regresi dalam mencari pengaruh antara keselamatan dan kesehatan kerja dengan produktivitas kerja karyawan.

Tabel 4. Hasil Uji Regresi

\begin{tabular}{|l|c|c|c|c|c|}
\hline \multirow{2}{*}{ Model } & \multicolumn{2}{|c|}{$\begin{array}{c}\text { Unstandardized } \\
\text { Coefficients }\end{array}$} & $\begin{array}{c}\text { Standa } \\
\text { rdized } \\
\text { Coeffi } \\
\text { cients }\end{array}$ & \multirow{2}{*}{$\mathrm{t}$} & \multirow{2}{*}{ Sig } \\
\cline { 2 - 6 } & $\mathrm{B}$ & Std. Error & Beta & & \\
\hline (Constant) & 29,026 & 4,592 & & 6,320 & 0,000 \\
\cline { 2 - 6 } K3 & 0,408 & 0,064 & 0,497 & 6,359 & 0,000 \\
\hline
\end{tabular}

Sumber: Hasil Olah Data SPSS (2017)

Dari Tabel 4 dapat diketahui konstanta (a) bernilai 29,026 dengan koefisien regresi (b) sebesar 0,408. Oleh karena itu, persamaan regresi yang dapat diperoleh dalam penelitian ini adalah:

$$
\begin{gathered}
Y=\mathbf{a}+\mathbf{b X} \\
\mathbf{Y}=\mathbf{2 9 , 0 2 6 + 0 , 4 0 8 X}
\end{gathered}
$$

Nilai a dan $\mathrm{b}$ diatas dapat diinterpretasikan sebagai berikut:

a. Konstanta sebesar 29.026 dapat diartikan jika keselamatan dan kesehatan kerja sama dengan $(X=0)$ atau tidak ada keselamtan dan kesehatan kerja, maka produktivitas kerja karyawan hanya sebesar 29.026.

b. Keselamatan dan kesehatan kerja memiliki nilai koefisien regresi linier sebesar 0,408. Hal tersebut berarti bahwa apabila keselamatan dan kesehatan kerja mengalami kenaikan satu-satuan maka produktivitas kerja karyawan akan mengalami peningkatan sebesar 0,408 satuan.

\section{Koefisien Determinasi}

Setelah koefisien korelasi diketahui, maka selanjutnya adalah menghitung koefisien determinasi, yaitu untuk melihat kemampuan variabel independen yaitu keselamaran dan kesehatan kerja $(\mathrm{X})$ dalam menerangkan variabel dependen yaitu produktivitas kerja karyawan (Y). Dimana jika $\mathrm{R}$ square mendekati angka 1, maka variabel independen tersebut memberikan hampir semua informasi yang dibutuhkan untuk memprediksi variasi variabel dependen.

Tabel 5. Hasil Koefisien Determinasi

\begin{tabular}{|r|c|r|r|r|}
\hline Model & $\mathrm{R}$ & $\begin{array}{c}\mathrm{R} \\
\text { Square }\end{array}$ & $\begin{array}{c}\text { Adjusted } \\
\text { R Square }\end{array}$ & $\begin{array}{c}\text { Std. Error of } \\
\text { the Estimate }\end{array}$ \\
\hline 1 & $.497^{\mathrm{a}}$ & .247 & .241 & 3.890 \\
\hline
\end{tabular}

Sumber: Hasil Olah Data SPSS (2017)

Berdasarkan Tabel 5 diperoleh angka $\mathrm{R}$ square atau koefisien determinasi sebesar 0,247 . Besarnya koefisien determinasi sama dengan $24,7 \%$, yang dimana nilai tersebut menunjukkan bahwa keselamatan dan kesehatan kerja berpengaruh terhadap produktivitas kerja sebesar 24,7\%. Sedangkan sisanya yaitu $75,3 \%$ produktivitas kerja karyawan di PT Papyrus Sakti Paper Mill dipengaruhi oleh faktorfaktor lain yang tidak diteliti dalam penelitian ini.

\section{Hasil Uji Hipotesis}

Berdasarkan hasil penelitian, pelaksananaan keselamatan dan kesehatan kerja berpengaruh positif dan signifikan terhadap produktivitas kerja karyawan PT Papyrus Sakti Paper Mill. Hal itu dapat dibuktikan dari hasil perhitungan $\mathrm{t}$ hitung $=$ $6,359>\mathrm{t}$ tabel $=1,979$ dan diperoleh signifikansi $\mathrm{t}<5 \%$ yaitu $0,000<0,05$. Berdasarkan hasil tersebut dapat disimpulkan bahwa $\mathrm{Ha}$ diterima dan $\mathrm{Ho}$ ditolak. Hal tersebut mengindikasikan bahwa keselamatan dan kesehatan keja akan meningkatkan produktivitas kerja karyawan

\section{KESIMPULAN DAN SARAN \\ Kesimpulan}

1. Pelaksanaan Keselamatan dan kesehatan kerja karyawan secara keseluruhan termasuk dalam kategori baik atau tinggi, meskipun dalam praktik dilapangan masih terdapat kecelakaan kerja yang diakibatkan dari kelalaian karyawan yang kurang disiplin dalam mentaati peraturan yang telah ditetapkan perusahaan dalam prosedur kerja, yang salah satunya dalam hal menggunakan 
alat pelindung diri (APD). Dimensi yang dijadikan pengukuran untuk variabel keselamatan dan kesehatan kerja ini terdiri dari 5 (lima) dimensi, yaitu mambuat kondisi kerja yang aman, pendidikan dan pelatihan, menciptakan lingkungan kerja yang sehat, pelayanan kebutuhan kesehatan karyawan dan pelayanan kesehatan. Nilai mean dari masing-masing dimensi pun termasuk dalam kategori baik.

2. Produktivitas kerja karyawan PT Papyrus Sakti Paper Mill termasuk dalam kategori tinggi, meskipun dilihat dari data produktivitas kerja karyawan, pencapaian target perusahaan terhadap kuantitas produk yang dihasilkan karyawan masih belum optimal. Pengukuran produktivitas kerja ini diukur dengan menggunakan dua dimensi yaitu efektivitas dan efisiensi dengan beberapa indikator yang secara keseluruhan menunjukkan tingkat produktivitas kerja yang baik.

3. Terdapat pengaruh yang positif antara pelaksanaan keselamatan dan kesehatan kerja terhadap produktivitas kerja karyawan di PT Papyrus Sakti Paper Mill sebesar $24,7 \%$, sedangkan sisanya $100 \%-24,7 \%=75,3 \%$ dipengaruhi oleh faktor-faktor lain, seperti pendidikan, keterampilan dalam bekerja, disiplin kerja, sikap dan etika kerja, motivasi, dan lain sebagainya.

\section{Saran}

1. Kecelakaan kerja yang disebabkan dari kelalaian karyawan yang melanggar atau tidak mengikuti aturan-aturan yang telah ditetapkan perusahaan, sebaiknya diberikan sanksi yang lebih tegas lagi untuk memberikan efek jera agar karyawan dapat menjadi lebih disiplin dan termotivasi untuk membuat kondisi kerja yang lebih aman yang terhindar dari kecelakaan kerja maupun penyakit yang mungkin muncul akibat kerja.

2. Manajemen perusahaan diharapkan dapat mengambil langkah-langkah perbaikan demi meningkatkan produktivitas kerja karyawan yang lebih optimal seperti perbaikan dari faktor perusahaannya salah satunya dengan meninjau kembali komitmen perusahaan terhadap keselamatan dan kesehatan kerja yang dapat menunjang produktivits karyawannya. Serta dari faktor pribadi karyawan dengan cara seperti meninjau kembali apakah jenis pekerjaannya sudah sesuai dengan kemampuan karyawan serta usia dan lama kerjanya, karena semakin tua dan semakin lama bekerja akan berakibat pada penurunan ketahanan tubuh karyawannya, sehingga dapat menurunkan konsentrasi yang dapat menyebabkan kecelakaan kerja dan penurunan produktivitas kerja karyawan.

\section{DAFTAR PUSTAKA}

Ardana, M. N. W, \& Utama, M. (2012). Manajemen Sumber Daya Manusia. Yogyakarta: Graha Ilmu

Hameed, A., \& Amjad, S. (2009). Impact of Design on Employees Prductivity: A Case Study of Banking Organizations of Abbottabad, Pakistan. Journal of Public Affairs, Administration and Management Vol. 3 Issue 1

Handoko, T. H. (2000). Manajemen Personalia dan Sumber Daya Manusia. Yogyakarta: Penerbit BPFE

Jackson, R. S., Schuler, \& Werner, S. (2011). Pengelolaan Sumber Daya Manusia edisi kesepuluh. Jakarta: Salemba Empat

Malthis, R. L., \& Jackson, J. H. (2010). Manajemen Sumber Daya Manusia. Jakarta: Salemba Empat

Mangkunegara, A. A., \& Prabu, A. (2011). Manajemen Sumber Daya Manusia Perusahaan. Bandung: Penerbit PT Remaja Rosdakarya.

Pangarso, W. R. (2014). Pengaruh Kesehatan dan Keselamatan Kerja Untuk Produktivitas Kerja. Studi Kasus: 
CV. Rigen Sarana Mukti Karanganyar, Surakarta.

Rachmawati, I. K. (2008). Manajemen

Sumber Daya Manusia. Yogyakarta:

Andi

Sedarmayanti. (2004). Manajemen Sumber

Daya Manusia. Bandung: PT Refika Aditama.

(2009). Manajemen Sumber

Daya Manusia. Bandung: PT Refika Aditama.

. (2010). Manajemen Sumber

Daya Manusia, Reformasi Birokrasi dan

Manajemen Pegawai Negeri Sipil.

Bandung: PT Refika Aditama.

Sinungan, M. (2009). Produktivitas Apa dan

Bagaimana. Jakarta: Bumi Aksara

Sunyoto, D. (2015). Manajemen dan

Pengembangan Sumber Daya Manusia.

Yogyakarta: CAPS (Center for

Academic Publishing Service

Tryono, A. (2012). Paradigma Baru

Manajemen Sumber Daya Manusia.

Yogyakarta: Oryza.

Widodo, S. E. (2008). Manajemen

Pengembangan Sumber Daya Manusia.

Yogyakarta: Pustaka Pelajar 